\title{
Immortalization of Human B Cells: Analysis of B Cell Repertoire and Production of Human Monoclonal Antibodies
}

\section{Elisabetta Traggiai}

\begin{abstract}
One of the major challenges in human B cell immunology field has been the objective to establish stable monoclonal cells lines that express the B cell receptor (BCR) on their cell surface and secrete antibodies. Such a system is extremely attractive not only for studying various aspect of BCR signaling but also for the generation of human monoclonal antibody and the analysis of the human B cell repertoire. This chapter describes an efficient method to immortalize and clone human B cells by Epstein-Barr Virus (EBV) transformation.
\end{abstract}

Key words: B cells, Cloning, Epstein-Barr Virus, Human B cell subsets, Human monoclonal antibodies, Immortalization, Polyclonal stimulation

\section{Introduction}

In recent years, it has become evident that there is a great need to develop in vitro methods allowing to analyze human $\mathrm{B}$ cell responses in order to understand their regulation in normal as well as pathological situation such as autoimmune disorders, immunodeficiency, and infection diseases (1). One of the main limitations is that mature B cells, naïve as well as memory, cannot be maintained efficiently in vitro. When $\mathrm{B}$ cells are cultured in vitro in the presence of CD40 ligand (CD40L), cytokines, BCR triggering and Toll-like receptor (TLR) agonists they do respond. However, as soon as the B cells respond they differentiate into terminal plasma cells (2). This process is accompanied by cell cycle arrest precluding the generation of long-term B cell lines. Recently, transduction of peripheral memory B cells with the transcriptional factors involved in the control of $\mathrm{B}$ cell proliferation and differentiation, $\mathrm{B}$ cell lymphoma-extra large (BCL-xl) and BCL-6, respectively, has allowed 
to immortalize and generate stable cell lines expressing BCR and are able to synthesize and secrete immunoglobulins (3).

Several approaches have been developed to dissect and investigate the molecular regulation of the human $\mathrm{B}$ cell repertoire. One successful method has been to combine immunoglobulin (Ig) gene repertoire analysis and Ig reactivity at the single cell level (4). This strategy has been successfully applied for autoimmunity and immunodeficiency questions, and for the first time in human for central and peripheral B cell tolerance (5).

Among the oldest techniques to generate stable human $\mathrm{B}$ cell lines is the immortalization with EBV (6). In the past, one of the major limitations was the very low efficiency of B cell infection and subsequent cloning (7). Thus, alternative methods to produce human monoclonal antibodies have been developed, such as immunization of transgenic mice expressing human Ig loci, phage display library, and humanization of mouse antibodies via genetic engineering (8-10).

We recently described an improved method to infect and immortalize human B cells with EBV, in the presence of the TLR9 agonist, CpG 2006, during viral transformation and cloning (11). We have used this method to isolate neutralizing as well as nonneutralizing antibodies against severe acute respiratory syndrome coronavirus (SARS-CoV) (11). These antibodies have been generated from one individual, who recovered from SARS infection. The obtained antibodies display a high in vitro potency to neutralize viral replication. This approach is not only applicable to the area of infectious diseases but also other clinical conditions, such as autoimmune diseases and cancer, and allows exploiting the breadth and the avidity of the human $\mathrm{B}$ cell repertoire $(12,13)$. The method consists of four sequential steps: (a) human B cell subset isolation, (b) EBV infection, (c) B cell cloning, and (d) screening (Fig. 1).

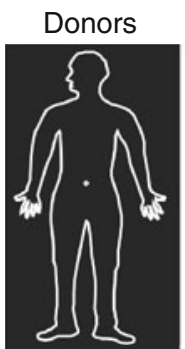

a. Antigen binding assay

b. Functional assay

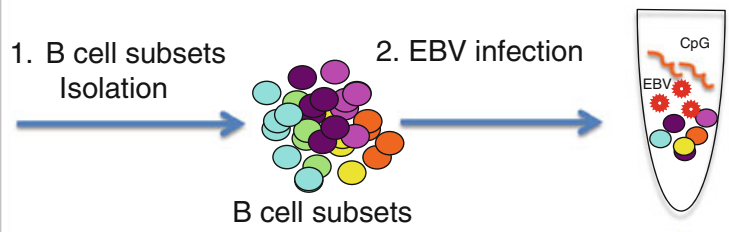

\section{B cell cloning}

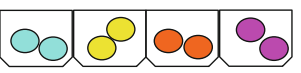

4. Screening strategies for specific antibodies

Fig. 1. Screening strategy for isolating antibodies from human B cells. Scheme of the different steps required for human B cell immortalization. 


\section{Materials}

2.1. Isolation of Human B Cells Subsets from PBMC

\subsection{B95.8 Cell \\ Expansion}

Epstein-Barr Virus B Cell Infection
1. Human peripheral blood mononuclear cells (PBMCs) or peripheral blood or cryopreserved mononuclear cells.

2. Phosphate-buffered saline (PBS) containing $2 \%$ fetal calf serum (FCS).

3. Ficoll-Hypaque density gradient.

4. CD22 or CD20 MicroBeads (Miltenyi Biotec, Bergisch Gladbach, Germany).

5. MACS buffer: PBS, $0.5 \%$ bovine serum albumin (BSA), $2 \mathrm{mM}$ EDTA, prepare fresh and keep on ice.

6. SuperMACS separator (Miltenyi Biotec).

7. Complete culture medium: RPMI 1640 (Gibco, Life Technologies, Carlsbad, CA, USA), sodium pyruvate (1 mM, Gibco), penicillin (100 U/mL, Gibco), streptomycin (100 $\mu \mathrm{g} /$ $\mathrm{mL}$, Gibco), kanamycin (100 $\mu \mathrm{g} / \mathrm{mL}$, Gibco), L-glutamine (2 mM, Gibco), nonessential amino acids (10 $\mu \mathrm{M}$, Gibco), 2-beta-mercaptoethanol $\left(5 \times 10^{-2} \mu \mathrm{M}\right), 10 \%$ FCS (Hyclone, ThermoScientific, Waltham, MA, USA).

8. LS column and LS column adaptor (Miltenyi Biotec.).

9. 5, 15, and $50 \mathrm{~mL}$ propylene conical tubes (Falcon, BD Biosciences, Franklin Lakes, NJ, USA).

10. Monoclonal antibodies for surface antigens to sort B cell subsets.

11. Refrigerated centrifuge.

12. Cell strainer, $40 \mu \mathrm{m}$ (Falcon cat. no. 352340, BD Biosciences).

13. BD FACSAria Cell Sorter (BD Biosciences).

1. EBV Virus, produced from B95.8 cell line (Sigma Aldrich, St. Louis, MO, USA).

2. Complete culture medium: RPMI 1640, sodium pyruvate (1 $\mathrm{mM})$, penicillin $(100 \mathrm{U} / \mathrm{mL})$, streptomycin $(100 \mu \mathrm{g} / \mathrm{mL})$, kanamycin $(100 \mu \mathrm{g} / \mathrm{mL})$, L-glutamine $(2 \mathrm{mM})$, nonessential amino acids $(10 \mu \mathrm{M}), 2$-beta-mercaptoethanol $\left(5 \times 10^{-2} \mu \mathrm{M}\right)$, $10 \%$ FCS.

3. $70 \%$ Ethanol.

4. 5, 15, and $50 \mathrm{~mL}$ propylene conical tubes (Falcon, BD Biosciences).

5. 6-Well tissue culture plates. 


\subsection{Epstein-Barr Virus B Cell Infection}

\subsection{EBV-B Cell Cloning Protocols}

2.5. ELISA Screening
1. Complete culture medium (see Subheading 2.1).

2. Sorted B cells (see Subheading 2.1).

3. CpG 2006, TLR9 agonist (CpG 2006, 5' TCg TCg TTT TgT CgT TTT gTC gTT 3' (phosphotio bonds)) (Invivogen, San Diego, CA, USA).

4. EBV virus (see Subheading 2.2).

1. Cell irradiator.

2. Ficoll-Hypaque density gradient.

3. Complete culture medium (see Subheading 2.1).

4. CpG 2006, TLR9 agonist (CpG 2006, 5' TCg TCg TTT TgT CgT TTT gTC gTT 3' (phosphotio bonds)).

5. Irradiated allogeneic PBMCs isolated from peripheral blood from normal donors.

6. EBV virus (see Subheading 2.2).

7. 384-Well plates (Corning-Costar, Corning Incorporated Life Sciences, Lowell, MA, USA).

8. Multichannel for 384 plates.

9. 5,15 , and $50 \mathrm{~mL}$ propylene conical tubes (Falcon).

10. Freezing media: 90\% FCS, 10\% DMSO.

11. Cryovials.

1. ELISA plates, medium binding (Greiner Bio-One, Frickenhausen, Germany).

2. Coating buffer: $\mathrm{Na}_{2} \mathrm{HPO}_{4} 0.1 \mathrm{M} \mathrm{pH} 9.6$ or PBS.

3. Blocking solution: PBS 10\% FCS.

4. Tween 20.

5. Developing buffer: $1.59 \mathrm{~g} \mathrm{Na}_{2} \mathrm{CO}_{3}, 2.93 \mathrm{~g} \mathrm{NaHCO}_{3}$, and $0.2 \mathrm{~g} \mathrm{NaN}_{3}$ in $1 \mathrm{~L}, \mathrm{pH} 9.6$.

6. ELISA substrate 104 , conc. $1 \mathrm{mg} / \mathrm{mL}$ in developing buffer (cat. no. N2765, Sigma-Aldrich).

7. Goat anti-human IgG alkaline phosphatase (cat. no. 2040-04, Southern Biotech, Birmingham, AL, USA).

\section{Methods}

\subsection{Isolation} of Human B Cells Subsets from PBMC
The human peripheral B cell pool is composed of cells at different stage of development, characterized by different signal requirements to differentiate into immunoglobulin secreting cells and carrying different Ig isotypes on the cell surface: (a) immature transitional 


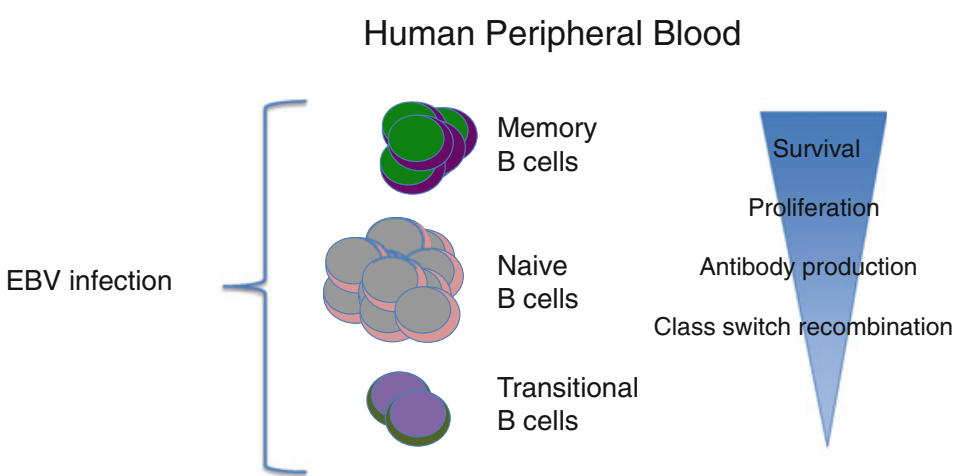

Fig. 2. Representation of the human peripheral $B$ cell pool, which can be transformed by EBV. As soon as B Cell mature from the transtional stage to the haire and then the memory stage some of the functional properties as survival, proliferation, antibody production and class switch recombination increase.

\section{Table 1}

\section{Summarization of antibody combinations}

\begin{tabular}{|c|c|c|}
\hline B cell subtype & Antibodies & Gating strategy \\
\hline Transitional immature B cells & $\begin{array}{l}\text { CD3, CD14, CD16 in PE-Cy5; } \\
\text { CD20 in PE-Cy7; CD24 in PE; } \\
\text { CD38 in FITC; IgG, IgA in APC }\end{array}$ & $\begin{array}{l}\mathrm{IgG} / \mathrm{A}^{-}, \mathrm{CD} 3 / 14 / 16^{-}, \\
\quad \mathrm{CD} 20^{+}, \mathrm{CD} 24^{\text {high }}, \mathrm{CD} 38^{\text {high }}\end{array}$ \\
\hline Naïve B cells & $\begin{array}{l}\text { CD3, CD14, CD16 in PE-Cy5; } \\
\text { CD20 in PE-Cy7; CD27 in } \\
\text { FITC; IgG/A in APC }\end{array}$ & $\begin{array}{l}\mathrm{IgG} / \mathrm{A}^{-}, \mathrm{CD} 3 / 14 / 16^{-} \\
\mathrm{CD} 20^{+}, \mathrm{CD} 27^{-}\end{array}$ \\
\hline IgM memory B cells & $\begin{array}{l}\text { CD3, CD14, CD16 in PE-Cy5; } \\
\text { CD20 in PE-Cy7; CD27 in } \\
\text { FITC; IgG/A in APC }\end{array}$ & $\begin{array}{l}\mathrm{IgG} / \mathrm{A}^{-}, \mathrm{CD} 3 / 14 / 16^{-} \\
\mathrm{CD} 20^{+}, \mathrm{CD} 27^{+}\end{array}$ \\
\hline IgG switch memory B cells & $\begin{array}{l}\text { CD3, CD14, CD16 in PE-Cy5; } \\
\text { CD20 in PE-Cy7; CD27 in } \\
\text { FITC; IgM/A in APC; IgD in PE }\end{array}$ & $\begin{array}{l}\mathrm{IgA} / \mathrm{M} / \mathrm{D}^{-}, \mathrm{CD} 3 / 14 / 16^{-} \\
\mathrm{CD} 20^{+}, \mathrm{CD} 27^{+}\end{array}$ \\
\hline Switch memory IgA B cells & $\begin{array}{l}\text { CD3, CD14, CD16 in PE-Cy5; } \\
\text { CD20 in PE-Cy7; CD27 in } \\
\text { FITC; IgM/G in APC; IgD in PE }\end{array}$ & $\begin{array}{l}\mathrm{IgG} / \mathrm{M} / \mathrm{D}^{-}, \mathrm{CD} 3 / 14 / 16^{-} \\
\mathrm{CD} 20^{+}, \mathrm{CD} 27^{+}\end{array}$ \\
\hline
\end{tabular}

B cells, (b) naïve B cells, (c) IgM memory B cells, and (d) switch memory B cells (Fig. 2). EBV can transform all peripheral resting $B$ cell subsets. To immortalize the desired human B cell subset immunomagnetic beads enrichment followed by cell sorting are sequentially applied for purification. Enriched B cells can be labeled with different combinations of monoclonal antibodies specific for surface antigens to identify and sort the B cell subpopulation of interest. A wide number of antibody combinations can be used and is summarized in Table 1 . 
1. Prepare mononuclear cells by Ficoll-Hypaque density gradient centrifugation from peripheral blood or thaw cryopreserved mononuclear cells (see Note 1 ).

2. Count cells and adjust cell concentration to $10^{7}$ cells per $265 \mu \mathrm{L}$ MACS buffer.

3. Add $65 \mu \mathrm{L}$ of CD22 (or CD20) microbeads per $10^{8}$ cells and incubate $30 \mathrm{~min}$ in the dark at $4^{\circ} \mathrm{C}$.

4. Add $10 \mathrm{~mL}$ of cold MACS buffer and centrifuge at $330 \times \mathrm{g}$ for $10 \mathrm{~min}, 4^{\circ} \mathrm{C}$. Carefully remove the supernatants by aspiration. Make sure not to disturb the pellet.

5. Resuspend cells in $4 \mathrm{~mL}$ of cold MACS buffer at a concentration of $2 \times 10^{8}$ cells $/ \mathrm{mL}$.

6. Insert the LS column adaptor in the magnetic field of the SuperMACS separator. Place the LS column into the adaptor and a $15 \mathrm{~mL}$ conical tube (see Note 2 ).

7. Prepare columns by rinsing with $4 \mathrm{~mL}$ cold MACS buffer. Discard the effluent and change the collection tube. Make sure that the LS columns does not run dry.

8. Transfer the cell suspension to the column and let flow through.

9. Wash three times by adding $3 \mathrm{~mL}$ of MACS buffer, add new buffer when the column is empty. Collect the effluent containing the $\mathrm{B}$ cell negative fraction.

10. Remove columns from the separator and place each on top of $15 \mathrm{~mL}$ propylene conical tubes.

11. Pipette $4 \mathrm{~mL}$ of cold MACS buffer onto columns. Flush the magnetically labeled cells by pushing the plunger into the column. Bring the volume of the cells to $10 \mathrm{~mL}$ with cold MACS buffer.

12. Centrifuge at $330 \times \mathrm{g}$ for $10 \mathrm{~min}$ at $4^{\circ} \mathrm{C}$ and carefully remove the supernatants by aspiration.

13. Resuspend the pellet in $2 \mathrm{~mL}$ of PBS $2 \%$ FCS in $5 \mathrm{~mL}$ propylene conical tubes.

14. After this step, cells are sorted according to B cell subset populations.

15. Dilute mAbs in $400 \mathrm{~mL}$ of PBS $2 \%$ FCS to stain the cells (see Table 2 for the dilution factor).

16. Centrifuge the $5 \mathrm{~mL}$ tube with the cells recovered from the enrichment, at $330 \times g$ per $10 \mathrm{~min}, 4^{\circ} \mathrm{C}$. Remove supernatants carefully.

17. Add mAbs solution to the pellet, and dissociate into single cell suspension by pipetting.

18. Incubate for $20 \mathrm{~min}$ in the dark, at $4^{\circ} \mathrm{C}$. 


\section{Table 2}

\section{Dilution factors}

\begin{tabular}{llll} 
mAb & Provider & Code/clone & Dilution \\
\hline CD3 Cy5 & Beckman Coulter & A07749/UCHTl & 1:100 \\
\hline CD14 Cy5 & Beckman Coulter & A07765/RMO52 & $1: 100$ \\
\hline CD16 Cy5 & Beckman Coulter & A07767/3G8 & $1: 100$ \\
\hline CD20 PECy7 & Beckman Coulter & IM/3629/B9E9 & $1: 50$ \\
\hline CD24 PE & BD, Pharmingen & $555428 /$ ML5 & $1: 50$ \\
\hline CD38 FITC & Beckman Coulter & A07778/T16 & $1: 100$ \\
\hline CD27 FITC & BD Pharmingen & $555440 / M-T 271$ & $1: 50$ \\
\hline IgG APC & Jackson ImmunoResearch & 109496098 & $1: 400$ \\
\hline IgM APC & Jackson ImmunoResearch & 109496 129 & $1: 400$ \\
\hline IgA APC & Jackson ImmunoResearch & 109496011 & $1: 400$ \\
\hline IgD PE & BD Pharmingen & $555779 /$ IA6-2 & $1: 100$ \\
\hline
\end{tabular}

19. Add $4 \mathrm{~mL}$ PBS, $2 \% \mathrm{FCS}$ and centrifuge at $330 \times g$ per $10 \mathrm{~min}$. Repeat this once.

20. Resuspend cells in $0.5 \mathrm{~mL}$ PBS, $2 \%$ FCS and filter the cell suspension with a cell strainer $(40 \mu \mathrm{m}$ nylon) into a fresh $5 \mathrm{~mL}$ tube in order to eliminate cellular aggregates that could interfere with the sorting procedure.

21. Prepare $15 \mathrm{~mL}$ collection tubes with $2 \mathrm{~mL}$ complete culture medium.

22. Sort with a BD FACSAria according to the desired phenotype (see Note 3).

3.2. B95.8 Cell

Expansion
1. Prewarm complete culture medium at $37^{\circ} \mathrm{C}$.

2. Thaw the cryo-preserved B95.8 cells by gently agitating the cryovial in a $37^{\circ} \mathrm{C}$ water bath.

3. In a sterile tissue culture hood spray the vial with $70 \%$ ethanol.

4. Very gently transfer the content of the vial in a $15 \mathrm{~mL}$ tube and add drop by drop up to $10 \mathrm{~mL}$ of warm complete medium.

5. Centrifuge at $330 \times g$ per $10 \mathrm{~min}$ at room temperature (RT).

6. Carefully aspirate the supernatants. Do not disturb the pellet.

7. Resuspend the cells in warm complete culture medium and transfer them in a 6 -well plates at $1 \times 10^{6} \mathrm{cell} / \mathrm{mL}$. Monitor cells for growth (see Note 4 ). 


\subsection{Epstein-Barr Virus B Cell Infection}

3.4. EBV-B Cell Cloning Protocols
8. After 10 days, remove all cells by centrifugation at $350 \times g$ for $10 \mathrm{~min}$.

9. Filter the supernatants with $0.8 \mu \mathrm{m}$ filters.

10. Aliquot the supernatants in polypropylene tube, $5 \mathrm{~mL}$ per tube, and store at $-80^{\circ} \mathrm{C}$ until used for EBV infection.

1. Add prewarmed complete medium up to $10 \mathrm{~mL}$ to sorted $\mathrm{B}$ cells, centrifuge at $330 \times g$ for $10 \mathrm{~min}$ at RT. Remove the supernatant carefully and add $1 \mathrm{~mL}$ of complete culture medium with CpG 2006 at $2.5 \mu \mathrm{g} / \mathrm{mL}$.

2. Add $1 \mathrm{~mL}$ of EBV virus (from Subheading 3.2), mix gently, and incubate for $5 \mathrm{~h}$ at $37^{\circ} \mathrm{C}, 5 \% \mathrm{CO}_{2}$ (tube cap open).

1. Prepare mononuclear cells by Ficoll-Hypaque density gradient of the allogeneic buffy coat. Resuspend cells in complete culture medium and irradiate at 6,000 rad. These cells will be used as feeder.

2. B cells infected with EBV are diluted in prewarmed complete culture medium containing: CpG $20062.5 \mu \mathrm{g} / \mathrm{mL}, 1 \% \mathrm{EBV}$, irradiated PBMCs at $2.5 \times 10^{5}$ cells $/ \mathrm{mL}$. Dispense $50 \mu \mathrm{L}$ of the cloning mixture with a multichannel pipette in 384-well plates. Different concentrations of B cells are plated at 25, 5, and 1 cells/well.

3. Complete medium with CpG $20062.5 \mu \mathrm{g} / \mathrm{mL}, 1 \% \mathrm{EBV}$, irradiated PBMCs at $2.5 \times 10^{5}$ cells $/ \mathrm{mL}$ without sorted $\mathrm{B}$ cells are dispensed in two 384-well plates. These plates are the negative control plates to check for potential overgrowth of irradiated feeder cells.

4. Plates are transferred into the incubator at $37^{\circ} \mathrm{C}, 5 \% \mathrm{CO}_{2}$.

5. After 7 days, check cells with a microscope for growth.

6. Supernatant of the growing clones is tested for the presence of the specific antibody by a binding or functional assay.

7. Specific clones are expanded in complete culture medium, without CpG 2006 and EBV.

8. As soon as the clones are growing, they can be frozen in $90 \%$ FCS, $10 \%$ DMSO. The minimum amount of EBV-B cells to be frozen is $5 \times 10^{6}$ per vial.

3.5. ELISA Screening

The screening strategy to select the "good" antibodies is a crucial part of the human antibody development. Humoral responses to vaccination or infection can be quantitatively but also qualitatively different. This reflects various level of protection in vivo, related to the differences in antibody function, which can be measured in vitro. All antibodies, which bind to a given antigen can be measured by enzyme-linked immunoabsorbent assay (ELISA). 
Alternatively, if the specific antigen can be expressed in the plasma membrane of a given cell line upon transfection of the relevant gene the binding of the antibody to the cell surface can be evaluated in flow cytometry. The ability to neutralize the specific pathogen in vitro is another possible measurement of antibody function.

1. Add $70 \mu \mathrm{L}$ antigen resuspended in coating buffer per well (final concentration $10 \mu \mathrm{g} / \mathrm{mL}$ ) in ELISA plates and incubate overnight at $4^{\circ} \mathrm{C}$ or $4 \mathrm{~h}$ at $\mathrm{RT}$.

2. Wash $3 \times$ with PBS, $0.05 \%$ Tween 20 .

3. Add $200 \mu \mathrm{L}$ of blocking solution PBS 10\% FCS, 2 h RT.

4. Wash $3 \times$ with PBS, $0.05 \%$ Tween 20.

5 . Add $50 \mu \mathrm{L}$ of B cell supernatant, incubate overnight at $4^{\circ} \mathrm{C}$.

6. Wash $3 \times$ with PBS, $0.05 \%$ Tween 20.

7. Add $50 \mu \mathrm{L}$ of anti-Ig-alkaline phosphatase $1 / 500$ in PBS $10 \%$ FCS, 2 h at RT.

8. Wash $3 \times$ with PBS, $0.05 \%$ Tween 20.

9. Add $100 \mu \mathrm{L}$ of ELISA substrate 104.

10. Read at absorbance of $405 \mathrm{~nm}$ in ELISA reader.

\section{Notes}

1. The number of B cells obtained from peripheral blood varies greatly between different donors. Percentage of peripheral B lymphocytes can range from 5 to $12 \%$ and this is age dependent. Usually elder people have fewer B cells. In order to minimize the loss of B cells, it is better to process the blood as soon as possible. Anti-coagulant such as heparin must be used. It is crucial to keep B cells on ice during all the different steps. Depletion of platelets form peripheral blood $(800 \mathrm{rpm} \times 8 \mathrm{~min}$ ), avoid the formation of clumps and aggregates. Also see Current Protocols in Immunology, Unit 7.1, April 2009.

2. These columns separate $1 \times 10^{8}$ magnetically labeled cells from up to $10^{9}$. Smaller or larger column are also available. Alternatively an automated column separator (e.g., autoMACS, Miltenyi) can be used.

3. In order to obtain a pure B cell population, it is necessary to use a positive selection method with immunomagnetic beads, followed by cell sorting. The positive selection method has the advantage that $\mathrm{B}$ cells are isolated with high degree of purity. However, unless Fab antibodies are used there is also the theoretical disadvantage that cells bearing high affinity $\mathrm{Fc}_{\mathrm{c}}$ receptors (monocytes), may bind to the antibodies. In addition, the 
antibodies utilized to select B cells, such as anti-surface Ig could provide a signal to the B cell that can influence the EBV infection. Indeed in all the antibodies combinations mentioned in Table 1 the surface Ig is used to negatively select the B cell population. Moreover, it is crucial to use anti-CD22 or CD20 microbeads to enrich B cells, instead of anti-CD19 microbeads. The latter induces the internalization of CD19 surface and consequently also of CD21, which is responsible for EBV entry into B cells (14).

4. Make sure that B95.8 do not grow in big clusters, some cells adhere to the plastic, and are intolerant to acid conditions. It is crucial to split them every 2 days with a $1 / 2$ or $1 / 3$ dilution factor. The goal is to gradually expand these cells to obtain the needed amount, which depends on the size of the infection you plan to perform. When the desired volume is reached, all cells maintenance procedures (including medium change) are stopped.

\section{References}

1. DiLillo DJ, Horikawa M, Tedder TF (2011) B-lymphocytes effector functions in health and disease. Immunol Res 49:281-292

2. Jourdan M, Caraux A, Caron G, et al (2011) Characterization of a transitional preplasmablast population in the process of human B cell to plasma cell differentiation. J Immunol 87:3931-3941

3. Kwakkenbos MJ, Diehl SA, Yasuda E, Bakker $A Q$, van Geelen CMM, Lukens MV, van Bleek GM, Widjojoatmodjo MN, Bogers WMJ, Mei $\mathrm{H}$, Radbruch A, Scheeren FA, Spits H, Beaumont T (2010) Generation of stable monoclonal antibody-producing $\mathrm{B}$ cell receptor-positive human memory B cells by genetic programming. Nat Med 16:123-129

4. Tiller T, Meffre E, Yurasov S, Tsuiji M, Nussenzweig MC, Wardemann H (2008) Efficient generation of monoclonal antibodies from single human B cells by single cell RT-PCR and expression vector cloning. J Immunol Methods 329(1-2):112-124

5. Meffre E, Wardemann H (2008) B-cell tolerance checkpoints in health and autoimmunity. Curr Opin Immunol 20:632-638

6. Steinitz M, Klein G, Koskimies S, Makel O (1977) EB virus-induced B lymphocyte cell lines producing specific antibody. Nature 269: 420-422

7. Kozbor D, Roder JC (1981) Requirements for the establishment of high-titered human monoclonal antibodies against tetanus toxoid using the Epstein-Barr virus technique. J Immunol 127:1275-1280
8. McCafferty J, Griffiths AD, Winter G, Chiswell DJ (1990) Phage antibodies: filamentous phage displaying antibody variable domains. Nature 348:552-554

9. Burton DR, Barbas CF III (1994) Human antibodies from combinatorial libraries. Adv Immunol 57:191-280

10. Jones PT, Dear PH, Foote J, Neuberger MS, Winter G (1986) Replacing the complementarity-determining regions in a human antibody with those from a mouse. Nature 321: 522-525

11. Traggiai E, Becker S, Subbarao K, Kolesnikova L, Uematsu Y, Gismondo MR, Murphy BR, Rappuoli R, Lanzavecchia A (2004) An efficient method to make human monoclonal antibodies from memory B cells: potent neutralization of SARS coronavirus. Nat Med $10: 871-875$

12. Traggiai E, Lunardi C, Bason C, Dolcino M, Tinazzi E, Corrocher R, Puccetti A (2010) Generation of anti-NAG-2 mAb from patients' memory B cells: implications for a novel therapeutic strategy in systemic sclerosis. Int Immunol 22(5):367-374

13. Lanzavecchia A, Bernasconi N, Traggiai E, Ruprecht CR, Corti D, Sallusto F (2006) Understanding and making use of human memory B cells. Immunol Rev 211:303-309

14. Fingeroth JD, Weis JJ, Tedder TF, Strominger JL, Biro PA et al (1984) Epstein-Barr virus receptor of human $\mathrm{B}$ lymphocytes is the $\mathrm{C} 3 \mathrm{~d}$ receptor CR2. Proc Natl Acad Sci U S A 81: $4510-4514$ 